ISSN 1392-3196 / e-ISSN 2335-8947

Zemdirbyste-Agriculture, vol. 103, No. 3 (2016), p. 243-250

DOI 10.13080/z-a.2016.103.031

\title{
Estimation of soil structure and physical state in the seedbed under different tillage and environmental conditions
}

\author{
Edvin NUGIS ${ }^{1}$, Aleksandras VELYKIS ${ }^{2}$, Antanas SATKUS ${ }^{2}$ \\ ${ }^{1}$ Estonian Crop Research Institute \\ J. Aamisepa 1, Jõgeva, Jõgeva vald, Estonia \\ E-mail: edvin.nugis@etki.ee \\ ${ }^{2}$ Joniškèlis Experimental Station, Lithuanian Research Centre for Agriculture and Forestry \\ Karpių 1, Joniškèlis, Pasvalys distr., Lithuania \\ E-mail: velykisalex@gmail.com
}

\begin{abstract}
Soil structure and physical state are the basis of the conditions in which the crops grow. Tillage is an important factor affecting soil physical environment. No or reduced tillage under Nordic conditions often causes deterioration of soil physical condition. The aim of the study is to estimate the soil structure and physical state in the seedbed under different tillage and environmental conditions in Estonia and Lithuania. The study involved conventional (ploughing), reduced (ploughless) and no tillage (direct drilling) treatments. The soil structure in the seedbed prepared for spring crops was estimated using the same equipment and the same methods of assessment. The soil structure was estimated by the structure ratio $\left(\mathrm{K}_{\text {str }}\right)$ and by the structure index $\left(\mathrm{B}_{\text {str }}\right)$ which were calculated according to the amount of wet-sieved mature soil. In Estonia, the experiments were carried out on different (Fragi-Stagnic Albeluvisol, Endoeutri-Mollic Cambisol, Endoeutri-Haplic Luvisol, Endosceleti-Mollic Gleysol, Gleyc Albeluvisol and Mollic Gleysol) sandy loam soils during the periods 1995-1997 and 2012-2014. The most favourable level of soil structure was determined in the conventionally tilled (ploughed) plots in Gleyic Albeluvisol, Fragi-Stagnic Albeluvisol and in Endoeutri-Haplic Luvisol. Different tillage under conditions of various soils in Estonia also had a significant impact on soil physical properties (bulk density, water content, field capacity) in the seedbed. In heavier soil (clay loam Endocalcari-Endohypogleyic Cambisol) in Lithuania 2011-2014 the most favourable soil structure level in the seedbed was also obtained using conventional ploughing. The worst seedbed structure in clay loam soil was under no tillage in autumn with a cover crop for winter mulch; however, in this treatment the seedbed contained higher soil water content compared to other tillage systems.
\end{abstract}

Key words: method of assessment, no tillage, physical properties, ploughing, ratio and index of soil structure, reduced tillage.

\section{Introduction}

Structure is a complex soil characteristic which includes genetic soil properties. Many environmental processes and technological conditions have an impact on soil structure, although the soil structure is not stable over time. Depending on the soil and crop management, the structure can vary in different soil layers (Morris et al., 2010; Mallory et al., 2011; Ciric et al., 2012; Myrbeck et al., 2012). Soils with a good structure are well aerated, quickly absorb rain water and slowly evaporate moisture. Such soils are characterized by a high microbial activity, they can be easily tilled. Soil structure strongly influences the growth of crops (Keller et al., 2007; Sustainable agriculture..., 2008; Munkholm et al., 2013). Altogether it is known that if the soil structure has a favourable level, the main conditions for plants are also favourable. Conversely, a poor structure does not provide proper plant growth and especially causes a lot of soil protection problems (Gallardo-Carrera et al., 2007; Muukkonen et al., 2009; Al-Kaisi et al., 2014).
Soil physical environment is the basis of conditions in which crops germinate, grow and develop. A number of soil-related factors (water content, temperature, bulk density, availability of oxygen, etc.) affect the crops immediately after sowing. Parameters of prepared seedbed affect the scale and nature of these factors. Therefore, a properly prepared seedbed is an important guarantee for crop germination, growth and productivity (Håkansson et al., 2002; 2011; Atkinson et al., 2007). Seedbed quality is one of the most important characteristics of soil physical condition. Different principles and methods are used to assess the quality of the seedbed in different countries. However, the key factor is the soil structure. According to Håkansson et al. (2002), soil aggregates of 2-5 mm size are considered as the most appropriate in the seedbed layer. It is important condition for good emergence of crops during droughty seasons that seeds in seedbed are covered with soil aggregates $50 \%$ of which are smaller than 5 mm (Håkansson et al., 2011). Morris et al. (2010) 
propose that in order to achieve good emergence of sensitive crops under the United Kingdom's conditions, up to $33 \%$ of aggregates finer than $5 \mathrm{~mm}$ are required in the seedbed. The parameters of structural soil aggregates, their stratification in the seedbed determine not only seed contact with the soil and seed germination rate, but also moisture, heat and air regime, growth of plant seedlings and roots, etc. (Atkinson et al., 2007; Gallardo-Carrera et al., 2007; Satkus, Velykis, 2008; Nugis, 2010).

In Estonia and Lithuania during the formerSoviet period, insufficient attention was paid to the problems with soil structure. The main goal then was the quantity of yield but not the quality or soil protection.

The aim of this study is to estimate the soil structure and physical state in the seedbed under different tillage and environmental conditions in Estonia and Lithuania using the same equipment and the same methods.

\section{Materials and methods}

Site and soil. The experiments were carried out at the Estonian Crop Research Institute during the periods 1995-1997 and 2012-2014 and at the Joniškèlis Experimental Station of the Lithuanian Research
Centre for Agriculture and Forestry during the period 2011-2014. The soils (classification by WRB - World Reference Base for Soil Resources) and different sites of experiments during the period 1995-1997 in Estonia were as follows: Endoeutri-Haplic Luvisol (Järva county, Väätsa - $\left.\mathrm{K}_{\mathrm{v}}, 58^{\circ} 56^{\prime} \mathrm{N}, 2^{\circ} 26^{\prime} \mathrm{E}\right)$, Endoeutri-Mollic Cambisol (Lääne-Viru county, Aaspere $-\mathrm{K}_{\mathrm{A}}, 59^{\circ} 27^{\prime} \mathrm{N}$, $\left.25^{\circ} 07^{\prime} \mathrm{E}\right)$, Endosceleti-Mollic Gleysol (Harju county, Saida BTK $-\mathrm{K}_{\mathrm{S}}, 59^{\circ} 04^{\prime} \mathrm{N}, 24^{\circ} 21^{\prime}$ E), Fragi-Stagnic Albeluvisol (Tartu county, Estonian University of Life Sciences, "Eerika" experimental field $-\mathrm{K}_{\mathrm{E}}, 58^{\circ} 23^{\prime} \mathrm{N}$, $26^{\circ} 44^{\prime}$ E). In 2012-2014, field experiments (Tamm et al., 2015) were carried out on the fields of permanent observation points. The soils and sites during this period were as follows: Gleyic Albeluvisol (South-Viljandi county, Abja-Paluoja, 58 $7^{\circ} 39^{\prime \prime} \mathrm{N}, 25^{\circ} 15^{\prime} 32^{\prime \prime} \mathrm{E}$ - trials $\mathrm{O} 2$, and K2), Fragi-Stagnic Albeluvisol (Valga county, Õru, 57 56 $31^{\prime \prime}$ N, 26 $6^{\circ} 17^{\prime \prime} \mathrm{E}$ - trials O3 and K3) and Mollic Gleysol (Pärnu county, Halinga, 58³8'18" N, $24^{\circ} 21^{\prime} 17^{\prime \prime} \mathrm{E}$ - trials O8 and K8).

The texture of Estonian soils is presented in Table 1, which shows that Estonian soils are sandy loams, but they are very different in the organic carbon $\left(\mathrm{C}_{\text {org }}\right)$.

Table 1. The soil texture and organic carbon $\left(\mathrm{C}_{\mathrm{org}}\right)$ content in Estonian soils (A-horizon)

\begin{tabular}{|c|c|c|c|c|c|}
\hline \multirow{3}{*}{ Soil group names } & \multicolumn{3}{|c|}{ Soil particle size $\mathrm{mm}$} & \multirow{3}{*}{$\begin{array}{l}\text { Soil texture } \\
\text { (FAO) }\end{array}$} & \multirow{3}{*}{$\begin{array}{c}\mathrm{C}_{\text {org }} \\
\%\end{array}$} \\
\hline & $\begin{array}{c}\text { sand } \\
>0.063\end{array}$ & $\begin{array}{c}\text { silt } \\
0.002-0.063\end{array}$ & $\begin{array}{c}\text { clay } \\
<0.002 \\
\end{array}$ & & \\
\hline & \multicolumn{3}{|c|}{ soil particle content $\%$} & & \\
\hline \multicolumn{6}{|c|}{ Determined during period 1995-1997 } \\
\hline Fragi-Stagnic Albeluvisol & 76 & 18 & 6 & sandy loam & 1.5 \\
\hline Endoeutri-Mollic Cambisol & 57 & 35 & 8 & sandy loam & 3.2 \\
\hline Endoeutri-Haplic Luvisol & 64 & 29 & 7 & sandy loam & 1.6 \\
\hline Endosceleti-Mollic Gleysol & 66 & 24 & 10 & sandy loam & 2.8 \\
\hline \multicolumn{6}{|c|}{ Determined during period $2012-2014^{*}$} \\
\hline Gleyic Albeluvisol & 63 & 31 & 6 & sandy loam & 1.4 \\
\hline Fragi-Stagnic Albeluvisol & 77 & 17 & 6 & sandy loam & 1.5 \\
\hline Mollic Gleysol & 69 & 22 & 9 & sandy loam & 3.0 \\
\hline
\end{tabular}

* - event manager PhD Kalvi Tamm

The experimental site in Lithuania is situated in the northern part of Central Lithuania's Lowland $\left(56^{\circ} 21^{\prime} \mathrm{N}, 24^{\circ} 10^{\prime} \mathrm{E}\right)$. The soil of the site is Endocalcari-

Endohypogleyic Cambisol with a texture of clay loam, moderately rich in $\mathrm{C}_{\text {org }}$ (Table 2).

Table 2. The soil texture and organic carbon $\left(\mathrm{C}_{\text {org }}\right)$ content in Lithuanian soil (A-horizon)

\begin{tabular}{|c|c|c|c|c|c|}
\hline \multirow{3}{*}{ Soil group name } & \multicolumn{3}{|c|}{ Soil particle size $\mathrm{mm}$} & \multirow{3}{*}{$\begin{array}{l}\text { Soil texture } \\
\text { (FAO) }\end{array}$} & \multirow{3}{*}{$\begin{array}{c}\mathrm{C}_{\text {org }} \\
\%\end{array}$} \\
\hline & $\begin{array}{c}\text { sand } \\
>0.063 \\
\end{array}$ & $\begin{array}{c}\text { silt } \\
0.002-0.063 \\
\end{array}$ & $\begin{array}{c}\text { clay } \\
<0.002 \\
\end{array}$ & & \\
\hline & \multicolumn{3}{|c|}{ Soil particle content $\%$} & & \\
\hline Endocalcari-Endohypogleyic Cambisol & 23 & 50 & 27 & clay loam & 1.3 \\
\hline
\end{tabular}

Investigated practices and general conditions of the experiments. Under Estonian environmental conditions, the effects of conventional tillage (CT) (ploughing at $20 \mathrm{~cm}$ depth) on soil structure and physical state in the seedbed for spring-sown crops were investigated on sandy loams during the period of 1995 1997 and the effects of conventional tillage (CT) and direct drilling (NT, no tillage) on the same parameters were studied during the period of 2012-2014.

The experiment on clay loam soil in Lithuania examined the effects of tillage systems on spring and winter crops. The following tillage systems were investigated: 1) deep ploughing at 20-23 cm depth, 2) shallow ploughing at $15-17 \mathrm{~cm}$ depth, 3) ploughless 
tillage at $10-12 \mathrm{~cm}$ depth, 4) ploughless tillage at 10$12 \mathrm{~cm}$ depth with lime sludge incorporation and 5) no tillage in autumn with a cover crop for winter mulch. Research was conducted in the crop rotation: 1) field pea (Pisum sativum L.), 2) winter wheat (Triticum aestivum L.), 3) spring oilseed rape (Brasica napus L.) and 4) spring barley (Hordeum vulgare L.). This article presents the quality indicators of seedbed, prepared for field pea and spring barley. Cover crops were as follows: before field pea growing - a mixture of white mustard (Sinapis alba L.) and oilseed radish (Raphanus sativus L.), before spring barley growing - oat (Avena sativa L.).

Experimental methods, assessments and statistical procedures. The soil structure in the seedbed was determined by the method and equipment of the Swedish University of Agricultural Sciences (Håkansson et al., 2002; Satkus, Velykis, 2008; Nugis, 2010) in Estonia during 1995-1997 and in Lithuania during 20112014. In 2012-2014, the soil samples of Estonian field experiments (event manager PhD Kalvi Tamm <http:// www.pikk.ee/upload/files/K_Tamm_RUP_2012_2014 lopparuanne.pdf $>$ ) were sieved by the equipment of USA Standard Testing Sieve. The soil of mature state was sieved in the wet conditions (method of wet sieving) directly in the field. Bores of top sieves in the equipment of USA Standard Testing Sieve have a diameter of 4.7 $\mathrm{mm}$, while bores of analogous sieves in the equipment of the Swedish University of Agricultural Sciences - a diameter of $5.0 \mathrm{~mm}$. However, the difference between the diameters in the methodological sense is not significant. Bottom sieves in both equipments have the same bores $2 \mathrm{~mm}$ in diameter. Therefore, we regard both methods as analogous. The amount of $<2 \mathrm{~mm}, 2-5$ or $2-4.75 \mathrm{~mm}$ and $>5 \mathrm{~mm}$ (by equipment of the Swedish University of Agricultural Sciences) or $>4.75 \mathrm{~mm}$ (by equipment of USA Standard Testing Sieve) soil aggregate fractions ( $\%$ $\mathrm{v} / \mathrm{v}$ ) was determined in the seedbed layer.

Suitable indices are necessary for the assessment of soil structure. Coefficient of soil structure $\mathrm{K}_{\text {str }}$ is calculated first (Nugis, 2010; Nugis et al., 2014). The coefficient of soil structure $\mathrm{K}_{\text {str }}$ (according to the data of soil wet sieving) is calculated by the equation:

$$
\mathrm{K}_{\mathrm{str}}=\frac{\mathrm{S}_{\mathrm{av}}}{\mathrm{S}_{\mathrm{n} 1}+\mathrm{S}_{\mathrm{n} 2}}
$$

where $s_{\text {av }}$ - amount of soil aggregates 2-4.75 $\mathrm{mm}, \%(\mathrm{v} / \mathrm{v})$ (USA Standard Testing Sieve) or amount of soil aggregates $2-5 \mathrm{~mm}, \%$ (v/v), (Swedish University of Agricultural Sciences), agronomy valuable soil aggregates; $\mathrm{s}_{\mathrm{n} 1}$ - amount of soil aggregates $<2 \mathrm{~mm}, \%$ $(\mathrm{v} / \mathrm{v})$, agronomy not valuable soil aggregates; $\mathrm{s}_{\mathrm{n} 2}-$ amount of soil aggregates, $>4.75$ or $>5 \mathrm{~mm}, \%(\mathrm{v} / \mathrm{v})$ which are also agronomy not valuable soil aggregates.

During long-term investigations we found that if $\mathrm{s}_{\mathrm{av}}=\mathrm{s}_{\mathrm{n} 1}+\mathrm{s}_{\mathrm{n} 2}$ then the $\mathrm{K}_{\mathrm{str}}=1$. When coefficient of soil structure $\mathrm{K}_{\text {str }}$ is equal to 1 , it is a maximum. In this case, the conditions of soil structure are favourable to the maximum. $\mathrm{K}_{\text {str }}$ may be less than 0.5 , when the soil is highly compacted, for example, after harvesting of potato in Estonia. In the present case the structure of the soil is poor, and the conditions are not appropriate for plant growth.

We found that it is possible to characterize the common structural condition of soil through corresponding index $\mathrm{B}_{\text {str }}$ of soil structure which could be calculated based on the data measured directly in the field:

$$
\mathrm{B}_{\text {str }}=\left(\mathrm{K}_{\mathrm{str}(\max )}-\mathrm{K}_{\mathrm{str(}(\mathrm{i})}\right) /\left(\mathrm{K}_{\mathrm{str}(\max )}-\mathrm{K}_{\mathrm{str( \operatorname {min } )}}\right)(2) \text {, }
$$

where $\mathrm{K}_{\text {str(i) }}$ - coefficient of soil structure, which is calculated based on the current measurements in the field.

The soil physical properties, i.e. dry bulk density $\left(\mathrm{Mg} \mathrm{m}^{-3}\right)$ and gravimetric soil water content $\left(\mathrm{kg} \mathrm{kg}^{-1}\right)$ were measured by Eijkelkamp's cylinder $\left(100 \mathrm{~cm}^{3}\right)$ in seedbed depth $(0-5 \mathrm{~cm})$. During the experimental periods, the samples were collected from the seedbed soil layer of spring-sown fields.

All results of Estonian experiments are based on three soil sample replicates. The field trial in Lithuania was arranged as a randomized single row design with four replicates.

The results were processed by analysis of variance using the software ANOVA. The data were compared using the least significant difference (LSD) test.

\section{Results and discussion}

Estonian soils are light, therefore, we determined mean $\mathrm{K}_{\text {str(min) }}=0.50$. When assessing the level of soil structure according to the numerical values of the soil structure index $\mathrm{B}_{\text {str }}$ in comparison with the values of the coefficient of soil structure $\mathrm{K}_{\text {str }}$ we have the opposite situation. With increasing of $\mathrm{B}_{\text {str }}$ numerical values, soil structure level falls, and when the $\mathrm{B}_{\text {str }}$ value decreases, the soil structure is improved. In contrast, increasing $\mathrm{K}_{\text {str }}$ numerical value shows the improvement of soil structure and decreasing $\mathrm{K}_{\text {str }}$ value indicates deterioration in the structure.

It is noteworthy that the equation (2) is bases on extreme structure ratios. The same principles have been used by Baumgartl and Köck (2004) who have described the volume changes of soil by combining theories of mechanics and hydraulic stresses. The same equation has been also used by other authors (Mouazen, Ramon, 2009; Mueller et al., 2009).

Coefficient of soil structure $\mathrm{K}_{\text {str }}$, soil structure index $\mathrm{B}_{\text {str }}$ and other indicators of soil physical properties of Estonian light soils are presented in Table 3. The assessment of soil structure and physical properties did not yield any significant relationship between different conditions of individual years of study in Estonia and tillage systems and soils investigated. Table 3 shows that the index $\mathrm{B}_{\text {str }}$ of soil structure in Estonian sandy loam soils usually varied between $0.91-0.95$. Index of soil structure $\mathrm{B}_{\text {str }}=0.99$ (Fragi-Stagnic Albeluvisol, NT) confirms a very poor soil structure. The most favourable level of soil structure is $\mathrm{B}_{\text {str }}=0.64$ (Gleyic Albeluvisol, CT) when every year during 2012-2014 soil ploughing was used. Favourable seedbed soil structure was also in the Fragi- 
Stagnic Albeluvisol $\left(\mathrm{B}_{\mathrm{str}}=0.76\right)$ and in the EndoeutriHaplic Luvisol $\left(\mathrm{B}_{\text {str }}=0.77\right)$ under conventional tillage conditions. Here, the differences compared with other soil structure were also significant. In our opinion, based on the results of these studies, the use of direct drilling technology and heavy machinery every year determines the deterioration of soil structure.

Soil dry bulk density in seedbed was often significantly different in various soils in Estonia depending on tillage system used (Table 3). Soil dry bulk density in Fragi-Stagnic Albeluvisol under NT reached $1.56 \mathrm{Mg}$ $\mathrm{m}^{-3}$ and was significantly by $52.9 \%$ higher compared to the same indicator in Endosceleti-Mollic Gleysol under $\mathrm{CT}$, where soil dry bulk density was the lowest of all the tested soils. High dry bulk density $\left(1.47 \mathrm{Mg} \mathrm{m}^{-3}\right)$ in the seedbed was also in Gleyic Albeluvisol (NT), where the indicator was significantly higher than in most of other soils. In Fragi-Stagnic Albeluvisol and Gleyic Albeluvisol soil dry bulk density significantly differed even between study sites, differing in tillage method used. Here, direct drilling (NT) resulted in significantly higher soil bulk density, compared to ploughing.

Soil gravimetric water content in the seedbed in various Estonian soils depending on applied tillage was often significantly different (Table 3). Mollic Gleysol, Gleyic Albeluvisol and Fragi-Stagnic Albeluvisol are characterized by the highest soil water content in the seedbed. The soil water content in Endoeutri-Mollic Cambisol under CT was the lowest $\left(0.127 \mathrm{~kg} \mathrm{~kg}^{-1}\right)$. Soil field capacity in various Estonian soils in many instances was also significantly different. Mollic Gleysol showed the highest soil field capacity (0.199 and $\left.0.200 \mathrm{~kg} \mathrm{~kg}^{-1}\right)$. Low soil field capacity is typical of Endosceleti-Mollic Gleysol and Gleyic Albeluvisol.

Table 3. Indicators of soil structure and physical properties in the seedbed for Estonian sandy loam soils

\begin{tabular}{|c|c|c|c|c|c|c|}
\hline Soils & $\begin{array}{c}\text { Tillage } \\
\text { systems }\end{array}$ & $\begin{array}{l}\text { Current soil } \\
\text { structure ratio } \\
\mathrm{K}_{\text {str(i) }}\end{array}$ & $\begin{array}{c}\text { Soil } \\
\text { structure index } \\
\mathrm{B}_{\mathrm{str}}\end{array}$ & $\begin{array}{c}\text { Soil dry } \\
\text { bulk density } \\
\mathrm{Mg} \mathrm{m}^{-3}\end{array}$ & $\begin{array}{c}\text { Soil } \\
\text { gravimetric } \\
\text { water content } \\
\mathrm{kg} \mathrm{kg}^{-1}\end{array}$ & $\begin{array}{c}\text { Soil field } \\
\text { capacity } \\
\mathrm{kg} \mathrm{kg}^{-1}\end{array}$ \\
\hline \multicolumn{7}{|c|}{ Determined during period 1995-1997 } \\
\hline Fragi-Stagnic Albeluvisol & CT & 0.35 & 0.76 & 1.19 & 0.170 & 0.164 \\
\hline Endoeutri-Mollic Cambisol & $\mathrm{CT}$ & 0.21 & 0.93 & 1.18 & 0.127 & 0.168 \\
\hline Endoeutri-Haplic Luvisol & $\mathrm{CT}$ & 0.34 & 0.77 & 1.25 & 0.168 & 0.187 \\
\hline Endosceleti-Mollic Gleysol & $\mathrm{CT}$ & 0.21 & 0.95 & 1.02 & 0.200 & 0.152 \\
\hline \multicolumn{7}{|c|}{ Determined during period 2012-2014 } \\
\hline \multirow{2}{*}{ Gleyic Albeluvisol } & NT & 0.33 & 0.81 & 1.47 & 0.233 & 0.153 \\
\hline & $\mathrm{CT}$ & 0.47 & 0.64 & 1.25 & 0.194 & 0.153 \\
\hline \multirow{2}{*}{ Fragi-Stagnic Albeluvisol } & NT & 0.16 & 0.99 & 1.56 & 0.208 & 0.160 \\
\hline & $\mathrm{CT}$ & 0.23 & 0.91 & 1.26 & 0.183 & 0.160 \\
\hline \multirow{2}{*}{ Mollic Gleysol } & NT & 0.31 & 0.92 & 1.31 & 0.276 & 0.199 \\
\hline & $\mathrm{CT}$ & 0.38 & 0.83 & 1.24 & 0.241 & 0.200 \\
\hline $\mathrm{LSD}_{05}$ & - & 0.019 & 0.027 & 0.156 & 0.033 & 0.071 \\
\hline
\end{tabular}

$\mathrm{CT}$ - conventional tillage (ploughing); NT - no tillage (direct drilling)

Research carried out on heavier soil (clay loam) in northern Lithuania showed that the mean soil minimum structure ratio $\mathrm{K}_{\text {str(min) }}$ in the seedbed prepared for spring-sown crops was as low as 0.15 . This indicates that in the case of seedbed preparation on clayey soils in unfavourable conditions, a very poor structure formed in it. Soil structure ratio $\mathrm{K}_{\text {str }}$, soil structure index $\mathrm{B}_{\text {str }}$ and other indicators of soil physical properties of Lithuanian heavy soils are presented in Tables 4 and 5. In the study conducted in Lithuania, the conditions of certain years did not result in significant impact of the investigated tillage systems on the changes of soil structure and other physical properties in the seedbed. On Lithuanian heavier soil, the soil structure index $\mathrm{B}_{\text {str }}$ in the seedbed prepared for field pea varied between $0.76-0.89$, depending on the tillage system used (Table 4). The most favourable

Table 4. Indicators of soil structure and physical properties in the seedbed prepared for field pea on Lithuanian clay loam soil during 2011-2014

\begin{tabular}{lcccc}
\hline \multicolumn{1}{c}{ Tillage systems } & $\begin{array}{c}\text { Current soil } \\
\text { structure ratio } \\
\mathrm{K}_{\text {str(i) }}\end{array}$ & $\begin{array}{c}\text { Soil } \\
\text { structure index } \\
\mathrm{B}_{\text {str }}\end{array}$ & $\begin{array}{c}\text { Soil dry } \\
\text { bulk density } \\
\mathrm{Mg} \mathrm{m}^{-3}\end{array}$ & $\begin{array}{c}\text { Soil gravimetric } \\
\text { water content } \\
\mathrm{kg} \mathrm{kg}^{-1}\end{array}$ \\
\hline Deep ploughing & 0.35 & 0.76 & 1.38 & 0.067 \\
Shallow ploughing & 0.34 & 0.78 & 1.40 & 0.070 \\
Ploughless tillage & 0.28 & 0.85 & 1.36 & 0.070 \\
Ploughless tillage with lime sludge & 0.31 & 0.81 & 1.31 & 0.076 \\
No tillage in autumn with winter mulch & 0.24 & 0.89 & 1.39 & 0.080 \\
\hline \multicolumn{1}{c}{ LSD $_{05}$} & 0.080 & 0.099 & 0.097 & 0.0116 \\
\hline
\end{tabular}


soil structure was created here using the conventional deep and shallow ploughing; soil structure index $\mathrm{B}_{\text {str }}$ in the seedbed reached 0.76 and 0.78 , respectively. The worst seedbed structure level $\left(\mathrm{B}_{\mathrm{str}}-0.89\right)$ in clay loam soil was under no tillage in autumn with a cover crop for winter mulch. According to soil structure index $\mathrm{B}_{\text {str }}$, the seedbed prepared for field pea was significantly worse due to no tillage in autumn with winter mulch compared to deep and shallow ploughing $\left(\mathrm{B}_{\mathrm{str}}\right.$ was respectively by $17.1 \%$ and $14.1 \%$ higher). The soil structure level in seedbed prepared for field pea under ploughless tillage and ploughless tillage with incorporation of lime sludge conditions was intermediate between conventional ploughing and no tillage in autumn with a cover crop for winter mulch.

The investigated tillage systems had no significant effect on soil dry bulk density in the seedbed. A seedbed prepared in clayey soils becomes over-dried very fast in spring. Therefore, soil water content in the seedbed prepared in Lithuanian clay loam was markedly lower than in the lighter soils in Estonia. Due to no tillage in autumn with winter mulch, the soil water content in the seedbed layer was significantly by $19.4 \%$ higher compared to deep ploughing.

Tillage systems, investigated on Lithuania's clay loam soil, had almost similar effects on soil structure and other physical properties in the seedbed prepared for spring barley, as well as in the seedbed prepared for field pea (Table 5). The soil structure index $\mathrm{B}_{\text {str }}$ in the seedbed prepared for spring barley varied between 0.69 0.80 . According to soil structure index $\mathrm{B}_{\text {str }}$, the seedbed prepared for spring barley was significantly worse due to no tillage in the autumn with winter mulch compared to deep ploughing and ploughless tillage with lime sludge incorporation ( $\mathrm{B}_{\text {str }}$ was by $15.9 \%$ higher respectively). The investigated tillage systems had no significant effect on soil dry bulk density in the spring barley seedbed. Having applied deep and shallow ploughing and ploughless tillage the seedbed prepared for spring barley had significantly lower soil water content (by 16.0, 20.0 and $16.0 \%$, respectively) compared to no tillage in the autumn with winter mulch.

Table 5. Indicators of soil structure and physical properties in the seedbed prepared for spring barley on Lithuanian clay loam soil during 2011-2014

\begin{tabular}{lcccc}
\hline \multicolumn{1}{c}{ Tillage systems } & $\begin{array}{c}\text { Current soil } \\
\text { structure ratio } \\
\mathrm{K}_{\text {str(i) }}\end{array}$ & $\begin{array}{c}\text { Soil } \\
\text { structure index } \\
\mathrm{B}_{\text {str }}\end{array}$ & $\begin{array}{c}\text { Soil dry } \\
\text { bulk density } \\
\mathrm{Mg} \mathrm{m}^{-3}\end{array}$ & $\begin{array}{c}\text { Soil gravimetric } \\
\text { water content } \\
\mathrm{kg} \mathrm{kg}^{-1}\end{array}$ \\
\hline Deep ploughing & 0.41 & 0.69 & 1.41 & 0.084 \\
Shallow ploughing & 0.39 & 0.72 & 1.41 & 0.080 \\
Ploughless tillage & 0.38 & 0.73 & 1.38 & 0.084 \\
Ploughless tillage with lime sludge & 0.41 & 0.69 & 1.36 & 0.089 \\
No tillage in autumn with winter mulch & 0.32 & 0.80 & 1.41 & 0.100 \\
\hline \multicolumn{1}{c}{ LSD $_{05}$} & 0.083 & 0.099 & 0.120 & 0.0133 \\
\hline
\end{tabular}

The level of soil structure in the seedbed prepared for spring barley (mean soil structure index $\mathrm{B}_{\text {str }}-0.73$ ) was significantly more favourable than that of soil structure in the seedbed prepared for field pea (mean soil structure index $\mathrm{B}_{\text {str }}-0.82$ ) (Table 6). These differences are caused by different pre-sowing tillage depth for field pea and spring barley. Field pea requires early sowing and greater sowing depths than spring barley. Field pea should be sown at 5-6 cm depth. Therefore, in our experiments the soil was tilled at 6-7 $\mathrm{cm}$ depth before field pea sowing, while at $4-5 \mathrm{~cm}$ depth for spring barley. In spring, the clayey soil in the deeper layers tends to be much wetter than in the surface. Therefore, larger and less valuable aggregates formed in the seedbed due deeper pre-sowing tillage for field pea. With predominant larger aggregates the seedbed, prepared for spring crops on clayey soils, quickly loses soil water. For this reason, after sowing significantly higher (by 20.8\%) soil water content was maintained in the seedbed prepared for spring barley, compared with the seedbed, prepared for field pea. It should be noted that the crops demanding deeper seedbed require careful choice of the most appropriate tillage time and proper implements in spring on heavy soils.

Table 6. Indicators of soil structure and physical properties in the seedbed prepared for different crops on Lithuanian clay loam soil during 2011-2014

\begin{tabular}{|c|c|c|c|c|}
\hline Crops & $\begin{array}{l}\text { Current soil structure ratio } \\
\qquad \mathrm{K}_{\text {str(i) }}\end{array}$ & $\begin{array}{l}\text { Soil structure index } \\
\mathrm{B}_{\mathrm{str}}\end{array}$ & $\begin{array}{l}\text { Soil dry bulk density } \\
\qquad \mathrm{Mg} \mathrm{m}^{-3}\end{array}$ & $\begin{array}{l}\text { Soil gravimetric } \\
\text { water content } \\
\mathrm{kg} \mathrm{kg}^{-1}\end{array}$ \\
\hline Field pea & 0.30 & 0.82 & 1.37 & 0.072 \\
\hline Spring barley & 0.38 & 0.73 & 1.39 & 0.087 \\
\hline $\mathrm{LSD}_{05}$ & 0.067 & 0.083 & 0.074 & 0.0140 \\
\hline
\end{tabular}


Poor seedbed soil structure is the main problem in heavy soils, which can cause poor emergence of seedlings. Spring sown crops emerge poorly in clayey soils during dry post-sowing periods as prepared seedbed is in most cases coarse and dries quickly. Håkansson et al. (2011) have reported that it is important that during dry post-sowing period seeds in the seedbed are covered with aggregates $50 \%$ of which are smaller than $5 \mathrm{~mm}$.

Silt fraction is dominant in Lithuanian clay loam soil and accounts for $50 \%$, while clay and sand fractions for $27 \%$ and $23 \%$, respectively (Table 2 ). In such clayey soil with predominant silty fraction capillary water rises quickly and goes up high. Therefore, clay loams may dry out quickly and more than sandy loams. Håkansson et al. (2011) reported that soils, containing more than $25 \%$ of clay, dry rapidly after the pre-sowing tillage in seedbed layer below the plant wilting point; however, in lighter soils the water content, available for plants usually remains up to the soil surface. It must be emphasized that in these clayey soils seedbed quality, especially its structure, is a deciding factor for seed germination in the spring, when after sowing droughty periods occur.

Tillage affects soil properties depending on soil type, implements used, soil condition during tillage, tillage depth and weather conditions. In various countries, studies lead to the conclusion that the conventional ploughing is superior compared with reduced tillage in the soils with poor physical properties and low organic carbon content. It has been noted that stable-structured and drier soils are more suited for reduced tillage (Morris et al., 2010; Feiza et al., 2011; Soane et al., 2012). Munkholm et al. (2013) pointed out that tillage and rotation are fundamental factors influencing soil quality. They have reported that poor soil structure was found for no tilled silt loam soil and diverse crop rotation is needed for optimal performance of no tilled soil. Al-Kaisi et al. (2014) have reported that the increase of large aggregates in no tilled soils is the result of soil structural stability, which is determined by minimum soil disturbance and presence of large amounts of crop residue on the soil surface. Keller et al. (2007) indicated that soils with poorer physical quality produce large amounts of clods $(>50 \mathrm{~mm})$. No clods are produced in soils when they are ploughed at the soil water content optimum for tillage.

It is noteworthy that the soil structure can be improved only by soil rational management. Preservation and improvement of soil structure as an important condition of soil quality as well as other physical properties can and must ensure adequate soil processes, high soil productivity potential and continuous good crop yield.

\section{Conclusions}

1. In relatively light soils (sandy loam FragiStagnic Albeluvisol, Endoeutri-Mollic Cambisol, Endoeutri-Haplic Luvisol, Endosceleti-Mollic Gleysol and Gleyic Albeluvisol), under Estonian conditions using conventional (ploughing) and no tillage (direct drilling) technologies the soil structure index $\left(\mathrm{B}_{\text {str }}\right)$ in the seedbed varied between 0.64-0.99. By using direct drilling in Fragi-Stagnic Albeluvisol the soil structure index $\left(\mathrm{B}_{\text {str }}=0.99\right)$ was maximum negative which pointed to poor soil structure. Most favourable level of soil structure $\left(\mathrm{B}_{\mathrm{str}}=0.64\right)$ was in the ploughed trial plots in Gleyic Albeluvisol. The seedbed in Fragi-Stagnic Albeluvisol and Gleyic Albeluvisol under direct drilling conditions had higher soil bulk density than the seedbed under conventional tillage. Mollic Gleysol, Gleyic Albeluvisol and Fragi-Stagnic Albeluvisol are characterized by the highest soil water content in the seedbed, while Endoeutri-Mollic Cambisol - by the lowest water content. Direct drilling mostly causes an increase of soil water content compared to conventional tillage. High soil field capacity is typical of Mollic Gleysol, whereas low soil field capacity - of Endosceleti-Mollic Gleysol and Gleyc Albeluvisol.

2. In relatively heavy soil(clay loam EndocalcariEndohypogleyic Cambisol), under Lithuanian conditions the soil structure index $\left(\mathrm{B}_{\mathrm{str}}\right)$ in the seedbed prepared for field pea varied between $0.76-0.89$, in the seedbed prepared for spring barley-between $0.69-0.80$, depending on the tillage system used. The most favourable heavy soil structure level in the seedbed was obtained using conventional ploughing. The worst seedbed structure in clay loam soil was under no tillage in the autumn with a cover crop for winter mulch. However, under no tillage with winter mulch, higher soil water content remains in the seedbed, as compared with the other tillage systems. Deeper seedbed preparation for field pea on clayey soil causes deterioration of soil structure and loss of soil water, compared to the shallower seedbed preparation for spring barley.

\section{Acknowledgments}

The authors wish to extend many thanks to all supporters: Emer. Prof. Inge Håkansson and also to Estonian colleagues: PhD (chair of ATO, ETKI) Kalvi Tamm, PhD-student Kersti Vennik (EULS), Priit Penu (PMK). Research findings from Lithuania, presented in the paper were obtained through the long-term research programme "Productivity and sustainability of agricultural and forest soils" implemented by Lithuanian Research Centre for Agriculture and Forestry, to whom the authors acknowledge their gratitude.

Received 18112015

Accepted 18052016 


\section{References}

Al-Kaisi M. M., Douelle A., Kwaw-Mensah D. 2014. Soil microaggregate and macroaggregate decay over time and soil carbon change as influenced by different tillage systems. Journal of Soil and Water Conservation, 69 (6): $574-580$ http://dx.doi.org/10.2489/jswc.69.6.574

Atkinson B. S., Sparkes D. L., Mooney S. J. 2007. Using selected soil physical properties of seedbeds to predict crop establishment. Soil and Tillage Research, 97 (2): 218-228 http://dx.doi.org/10.1016/j.still.2007.09.017

Baumgartl T., Köck B. 2004. Modeling volume change and mechanical properties with hydraulic models. Soil Science Society of America Journal, 68 (1): 57-65 http://dx.doi.org/10.2136/sssaj2004.5700

Ciric V., Manojlovic M., Nesic L., Belic M. 2012. Soil dry aggregate size distribution: effects of soil type and land use. Journal of Soil Science and Plant Nutrition, 12 (4): 689-703 http://dx.doi.org/10.4067/s0718-95162012005000025

Gallardo-Carrera A., Leonard J., Duval Y., Dürr C. 2007. Effects of seedbed structure and water content at sowing on the development of soil surface crusting under rainfall. Soil and Tillage Research, 95: 207-217 http://dx.doi.org/10.1016/j.still.2007.01.001

Feiza V., Feiziene D., Kadziene G., Lazauskas S., Deveikyte I., Slepetiene A., Seibutis V. 2011. Soil state in the $11^{\text {th }}$ year of three tillage systems application on the cambisol. Journal of Food, Agriculture and Environment, 9 (3-4): 311-328

Håkansson I., Myrbeck Å., Etana A. 2002. A review of research on seedbed preparation for small grains in Sweden. Soil and Tillage Research, 64 (1-2): 23-40 http://dx.doi.org/10.1016/S0167-1987(01)00255-0

Håkansson I., Arvidsson J., Rydberg T. 2011. Effects of seedbed properties on crop emergence: 2 . Effects of aggregate size, sowing depth and initial water content under dry weather conditions. Acta Agriculturae Scandinavica, Section B: Soil and Plant Science, 61 (5): 469-479 http://dx.doi.org/10.1080/09064710.2010.506447

Keller T., Arvidsson J., Dexter A. R. 2007. Soil structures produced by tillage as affected by soil water content and the physical quality of soil. Soil and Tillage Research, 92: $45-52$ http://dx.doi.org/10.1016/j.still.2006.01.001

Mallory J. J., Mohtar R. H., Heathman G. C., Schulze D. G., Braudeau E. 2011. Evaluating the effect of tillage on soil structural properties using the pedostructure concept. Geoderma, 163 (3-4): 141-149 http://dx.doi.org/10.1016/j.geoderma.2011.01.018

Morris N. L., Miller P. C. H., Orson J. H., Froud-Williams R. J. 2010. The adoption of non-inversion tillage systems in the United Kingdom and the agronomic impact on soil, crops and the environment - a review. Soil and Tillage Research, 108: $1-15$ http://dx.doi.org/10.1016/j.still.2010.03.004

Mouazen A. M., Ramon H. 2009. Expanding implementation of an on-line measurement system of topsoil compaction in loamy sand, loam, silt loam and silt soils. Soil and Tillage Research, 103: 98-104 http://dx.doi.org/10.1016/j.still.2008.09.012

Mueller L., Kay B. D., Chunsheng H., Li Y., Schindler U., Behrendt A., Sheperd T. G., Ball B. C. 2009. Visual assessment of soil structure: Evaluation of methodologies on sites in Canada, China and Germany. Part I: Comparing visual methods and linking them with soil physical data and grain yield of cereals. Soil and Tillage Research, 103: $178-187$

http://dx.doi.org/10.1016/j.still.2008.12.015

Munkholm L. J., Heck R., Deen B. 2013. Long-term rotation and tillage effects on soil structure and crop yield. Soil and Tillage Research, 127: 85-91 http://dx.doi.org/10.1016/j.still.2012.02.007

Muukkonen P., Hartikainen H., Alakukku L. 2009. Effect of soil structure disturbance on erosion and phosphorus losses. Soil and Tillage Research, 103: 84-91 http://dx.doi.org/10.1016/j.still.2008.09.007

Myrbeck Å., Stenberg M., Arvidsson J., Rydberg T. 2012. Effects of autumn tillage of clay soils on mineral $\mathrm{N}$ content, spring cereal yield and soil structure over time. European Journal of Agronomy, 37 (1): 96-104 http://dx.doi.org/10.1016/j.eja.2011.11.007

Nugis E. 2010. Seedbed quality preparation in Estonia. Agronomy Research, 8 (spec. iss. 2): 421-426

Nugis E., Lüüs L., Kuht J. 2014. Results of express-diagnostics evaluation of soil basing on penetration resistance measuring. Annals of Warsaw University of Life SciencesSGGW. Agriculture, 64: 15-24

Satkus A., Velykis A. 2008. Modelling of seedbed creation for spring cereals in clayey soils. Agronomy Research, 6 (spec. iss.): $329-339$

Soane B. D., Ball B. C., Arvidsson J., Basch G., Moreno F., Roger-Estrade J. 2012. No-till in northern, western and south-western Europe: a review of problems and opportunities for crop production and the environment. Soil and Tillage Research, 118: 66-87 http://dx.doi.org/10.1016/j.still.2011.10.015

Sustainable agriculture on productive soils. 2008 / compiled by Maikštennienė S. Lithuanian Institute of Agriculture, 344 p. (in Lithuanian)

Tamm K., Viil P., Vettik R., Võsa T., Kadaja J., Saue T., Edesi L., Sooväli P., Loorits L., Lauringson E., Talgre L., Penu P., Köster T., Sepp K., Akk E., Siim J., Plakk T., Nugis E., Pannal A., Põldoja R. 2015. Complex applied research for different cultivation methods (incl. direct drilling). Final report of project (RUP-Programme) <http://www.pikk. ee/upload/files/K_Tamm_RUP_2012_2014_lopparuanne. pdf $>$ [accessed 1811 2015] (in Estonian) 
ISSN 1392-3196 / e-ISSN 2335-8947

Zemdirbyste-Agriculture, vol. 103, No. 3 (2016), p. 243-250

DOI 10.13080/z-a.2016.103.031

\title{
Dirvožemio struktūros ir fizikinès būklès sẻklų guoliavietẻje ivertinimas skirtingo žemès dirbimo ir aplinkos sąlygomis
}

\author{
E. Nugis ${ }^{1}$, A. Velykis ${ }^{2}$, A. Satkus ${ }^{2}$ \\ ${ }^{1}$ Estijos augalininkystès institutas \\ ${ }^{2}$ Lietuvos agrarinių ir miškų mokslų centro Joniškèlio bandymų stotis
}

\section{Santrauka}

Dirvožemio struktūra ir fizikinė būklè yra svarbi augalų augimo sąlyga. Žemès dirbimas yra svarbus veiksnys, turintis ịtakos dirvožemio fizikinei būklei. Supaprastintas žemès dirbimas arba tiesioginè sèja Šiaurès Europos sąlygomis dažnai lemia dirvožemio fizikinių savybių prastėjimą. Tyrimų tikslas - ịvertinti žemès dirbimo ir sèjos technologijų be žemès dirbimo įtaką sèklų guoliavietès dirvožemio struktūrai bei fizikinei būklei Estijos ir Lietuvos sąlygomis. Tirta tradicinis (arimas) bei supaprastintas (bearimis) dirbimas ir tiesioginè sèja. Dirvožemio struktūra sèklų guoliavieteje, paruoštoje vasariniams augalams, buvo nustatyta vienodais prietaisais ir ịvertinta taikant tuos pačius metodus. Dirvožemio struktūra vertinta pagal struktūros santykị $\mathrm{K}_{\text {str }}$ ir struktūros indeksą $\mathrm{B}_{\text {stro }}$, kurie buvo apskaičiuoti pagal drègno fizinès brandos dirvožemio sijojimo rezultatus. Estijoje įvairiuose (FragiStagnic Albeluvisol, Endoeutri-Mollic Cambisol, Endoeutri-Haplic Luvisol, Endosceleti-Mollic Gleysol, Gleyic Albeluvisol ir Mollic Gleysol) lengvo priemolio dirvožemiuose tyrimai atlikti 1995-1997 ir 2012-2014 m. Tinkamiausia dirvožemio struktūra nustatyta tradicinį žemès dirbimą (arimą) taikant Gleyic Albeluvisol, FragiStagnic Albeluvisol ir Endoeutri-Haplic Luvisol dirvožemiuose. Estijoje dirvožemio fizikinès savybės (tankis, drègmès kiekis, vandentalpa) sèklų guoliavietėje priklausė nuo dirvožemio tipo ir taikyto žemès dirbimo būdo. Lietuvos sunkesniame dirvožemyje (sunkiame priemolyje, Endocalcari-Endohypogleyic Cambisol) tradicinis arimas 2011-2014 m. taip pat lèmè tinkamiausią sèklų guoliavietės dirvožemio struktūrą. Prasčiausia sẻklų guoliavietès struktūra sunkaus priemolio dirvožemyje nustatyta rudeni žemės visai nedirbant ir paliekant tarpinio pasèlio augalų mulčią žiemai. Tačiau šiuo atveju sẻklų guoliavietèje išliko daugiau drègmès nei taikant kitas žemės dirbimo sistemas.

Reikšminiai žodžiai: arimas, fizikinės savybės, struktūros santykis ir indeksas, supaprastintas dirbimas, tiesioginė sèja, vertinimo metodas.

Please use the following format when citing the article:

Nugis E., Velykis A., Satkus A. Estimation of soil structure and physical state in the seedbed under different tillage and environmental conditions. Zemdirbyste-Agriculture, 103 (3): 243-250 DOI 10.13080/z-a.2016.103.031 